\title{
Sustainability Index of Watershed Using Environmental Restoration Approach
}

Haqqi Annazili ${ }^{1{ }^{*}}$, Mahawan Karuniasa $^{1}$, and Muchamad Saparis Soedarjanto ${ }^{2}$

${ }^{1}$ School of Environmental Science, Universitas Indonesia, Building C Floor V-VI, Jalan Salemba Raya 4 Salemba, Jakarta 10430

${ }^{2}$ Directorate of Protection Forest Protected Areas, Directorate General of Watershed Management and Protection Forest Building

Manggala Wanabakti, Block I Floor 12 Jl. Gatot Subroto, Senayan, Central Jakarta.

\begin{abstract}
The condition of the Upper Ciliwung Watershed's Minimum Erosion Hazard value is still far from expected, since the value is still greater than one. The sustainability of watershed functions is influenced by the value of Minimum Erosion Hazard Rate, Farmer's Revenue, and Food Crop Production Results. The purpose of this research is to build calculation method of Sustainability Index of Watershed Function (IKFD) of Upper Ciliwung and to know the condition of Upper Ciliwung Watershed sustainability. The method of this research is mix method that combine quantitative and qualitative data. Data analysis was done by using Analytical Hierarchy Process (AHP). Based on the method used in this study, the authors build the calculation formula IKFD as follows: IKFD $=($ ITBEM x $72.8 \%)+($ IPPet $x$ $15.3 \%)+($ IPTPa $\times 11.9 \%)$. The final calculation of IKFD Upper Ciliwung is done through the sum of the multiplication of the AHP value of each indicator with the real condition value of each indicator. After the Upper Ciliwung Watershed Index is obtained, then it is categorized into category classes based on the distribution of figures in the index calculation. The Sustainability Index Value of Upper Ciliwung Watershed Function at present is $30.7 \%$ and goes into very less level.
\end{abstract}

Keywords: watershed; sustainability index; environmental restoration.

\section{Introduction}

The condition of the Minimum Erosion Hazard Level of the Upper Ciliwung Watershed shows that the number is still far from the expected one, since the value is still greater than one. Sustainable conditions in the Watershed can be achieved if the Minimum Erosion Hazard (TBEM) velue is $\leq 1$ or potential erosion value is less than the maximum tolerable erosion value [18]. Therefore, efforts are needed to obtain the sustainability of the ecosystem function of the Upper Ciliwung Watershed through environmental restoration, especially for erosion control and food and income fulfillment.

The average value of tolerable erosion (average E Tol) in Upper Ciliwung Watershed is 25.7 ton/hectare/year. While maximum tolerable erosion (maximum $\mathrm{E} \mathrm{Tol)}$ is 27 ton/hectare/year [12]. The condition of erosion value (potential erosion, maximum tolerable erosion, and TBEM), in the Upper Ciliwung Watershed are as follows: 102.40 tons/hectare/year; 27 ton/hectare/year; and 4.14.

The value of Potential Erosion is obtained by the following formula:

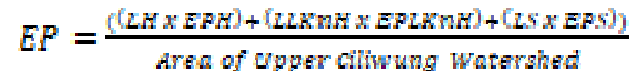

Note:

EP: Potential Erosion

LH: Forest Area

\footnotetext{
*Corresponding author: daulayhaqqi@gmail.com
}

EPH: Potential Forest Erosion

LLKnH: Non Forest Forest Area

EPLKnH: Potential Non Dry Forest Potential Erosion

LS: Wetland Area

EPS: Potential Wetland Erosion

The value of Minimum Erosion Hazard Level (TBEM) is obtained by the following formula:

$$
T B E M=\frac{z p}{\text { Maximum } Z T d}
$$

Note:

EP: Potential Erosion

Maximum E Tol: Maximum tolerable erosion

The sustainability of watershed functions is influenced by the value of the Minimum Erosion Hazard Level, Farmer's Revenue, and Food Crop Production figures which is an approach of environmental, economic and social aspects in the management of a watershed. Types of land cover are attempted to optimize the factors that influence the sustainability of watershed functions. Types of land cover include forests, dryland farming, rice fields and settlements. The purpose of this research is to: 1.) compile the calculation method of Watershed Sustainability Indicator (IKFD) of Upper Ciliwung and 2.) know the condition of Upper Ciliwung watershed sustainability. 


\section{Research Methods}

This research was conducted for five months, namely at the end of October 2017 until the third week of March 2018. Activities carried out include primary and secondary data collection, data processing and data analysis obtained. The location of this research is in Upper Ciliwung Watershed which mostly located in Bogor Regency, West Java Province.

The width of Upper Ciliwung Watershed is 15,225.12 hectares. The study population is all land cover located in Upper Ciliwung Watershed. Research sample is land owned by farmer household of land user. This research uses purposive sampling method. The number of sampling units used is 30 units of land belonging to the land user farmers, consisting of 19 sampling units on the farmers' forest land and 11 sampling units in the nonforest farmer's household.

In addition to the above populations, this study also uses expert respondents for AHP analysis in terms of policy formulation of environmental restoration model for sustainability of Upper Ciliwung Watershed. Expert respondents consist of two groups of stakeholders involved in the restoration of the watershed environment. The number of samples of the AHP method consists of:

1.) Government

The number of research samples from this government element amounted to 7 people.

2.) Academics

The sample of academics included in the expert stakeholder in this study came from college lecturers. Sample of academics amounted to 1 lecturer from the School of Environmental Sciences of the Universitas Indonesia.

\subsection{Data Collection, Processing and Analysis 2.1.1 Data on Food Crop Production}

In addition, to obtain the food crop production index, the food crop production data obtained above is converted first into the productivity of agricultural land for food crops. The formula for obtaining agricultural productivity figures for crops can be seen in Formula (3).

$$
\text { Pptpa }=\frac{p T p_{a}}{L}
$$

$\begin{array}{ll}\text { Note: } & \\ \text { Pptpa }= & \begin{array}{l}\text { Productivity of agricultural land for food } \\ \text { crops (ton/hectare/year) }\end{array} \\ \text { PTPa }= & \text { Crop production (ton/year) } \\ \mathrm{L} & =\text { Area (hectare) }\end{array}$

\section{Findings}

\subsection{TBEM Condition}

The Minimum Erosion Hazard (TBEM) level of Upper Ciliwung Watershed for the period of 2013-2016 is greater than 1 . In fact, the upstream Ciliwung watershed ecosystem is in sustainable condition if the value of TBEM is $\leq 1$ [18]. This shows that the condition of Upper Ciliwung watershed ecosystem can not be said to be sustainable because the potential erosion is greater than the maximum tolerable erosion.

\subsection{Farmers Income Conditions}

The total income of farmer households between the two groups (forest farmers and non-forest farmers) can be seen in Table 1.

Table 1. Characteristics of Farmers Income in Upper Ciliwung Watershed

\begin{tabular}{|c|c|}
\hline Type of Income & $\begin{array}{c}\text { Average Amount } \\
\text { (Rp) }\end{array}$ \\
\hline Main Revenue in a Month & $1,376,666.67$ \\
\hline Total Basic Income in a Year & $16,520,000$ \\
\hline Side Income within a Month & $628,333.33$ \\
\hline Total Side Income in a Year & $7,540,000$ \\
\hline $\begin{array}{c}\text { Total Revenue and Side Income in a } \\
\text { Year }\end{array}$ & $24,060,000$ \\
\hline
\end{tabular}

Source: self-processed from primary data

Revenue of farmers in the Upper Ciliwung Watershed per year when compared to the highest farmers Revenue in a region/part of another watershed that has similar characteristics to the Upper Ciliwung Watershed when viewed from the social, economic, geomorphological or provincial/island/similarity based on the soil type aspect. The soil type in question (according to the study area) is dominant: latosol, andosol, and regosol. Soil type is one of the things that determine the value of erosion [13]. In this case, the area that meets these criteria is Batu City (Brantas Watershed). Thus, the result of comparison of household income of farmers in Upper Ciliwung watershed with income of farmer household in Batu (Brantas Watershed) is 1:1.65.

\subsection{Condition of Food Crop Production}

Production of food crops in Upper Ciliwung watershed decreased during the period of 2013-2016 are as follows $30,272.50$ ton; $27,302.34$ ton; $25,617.83$ ton [3-8].

As a measure of the success of food crop production and as an indicator of food availability, based on food crop production data, calculation of food availability index. The result of calculation of Food Availability Index (IKP) of Ciliwung Hulu Watershed in 2013, 2015 and 2016 are as follows: $0.78 ; 0.70$; and 0.62 .

Based on the category of IKP, the value of IKP of Upper Ciliwung Watershed in the period of 2013 and 2015 is in the category of vulnerable and in 2016 is in very vulnerable category, so it can be said that there are conditions of unsustainability of food supply function in 
Upper Ciliwung watershed ecosystem for the period of 2013, 2015 and 2016. The states that the level of land vulnerability is high up to very high often found in the area of Bogor Regency [13].

\subsection{Preparation of Calculation Method of Sustainability Indicator of Watershed Function (IKFD) of Upper Ciliwung}

Analytical Hierarchy Process (AHP) method, as one of method of determining the weight of indicators of sustainability of Upper Ciliwung Watershed function is based on expert opinion. Based on the results of Analytical Hierarchy Process (AHP), we obtain the indicators of sustainability of Upper Ciliwung Watershed as follows:

a.) Minimum Erosion Hazard (TBEM) level of 0.728 or $72.8 \%$

b.) Farmers income of 0.153 or $15.3 \%$

c.) Production of Food Crops by 0.119 or $11.9 \%$

In order to gain weight through the AHP method approaching a more realistic condition in the field, then the weight is performed refinement. The enhancement is the addition of the element of real condition indicator comprising: Minimum Hazard Hazard (TBEM), Farmers Income, and Food Crop Production expressed as a number (percent). Furthermore, the figures for the calculation of the real conditions of the indicator are referred to as the Minimum Erosion Hazard Index (TBEM), Farmers Income Index, and Food Crop Production Index.

Each indicator of sustainability index of Upper Ciliwung Watershed function that already has a weight based on Analytical Hierarchy Process (AHP) result is then multiplied by each of the calculation result of real condition indicator of sustainability of watershed function (Minimum Erosion Hazard Index (TBEM), Farmers Income Index, and Food Crop Production Index). Furthermore, each of the multiplication result is summed up. Here are the results of compilation method calculation Sustainability Indicator of Watershed Cycle (IKFD) of Upper Ciliwung:

$$
\begin{aligned}
& I K F D=(\text { ITBEM } x \quad 72.8 \%)+(\text { IPPet } x \\
& 15.3 \%)+(\text { IPTPa } x 11.9 \%)
\end{aligned}
$$

Note

IKFD $=$ Sustainability Index of Upper Ciliwung Watershed Function

ITBEM $=$ Minimum Erosion Hazard Index

IPPet $=$ Farmers Income Index

IPTPa $=$ Food Crop Production Index

\subsubsection{Indicator}

3.4.1.1 Minimum Erosion Danger Rate (TBEM)
The researcher determines second requirement to be benchmark in this research, which is the value of TBEM $\leq 1$.

The Minimum Erosion Danger Rate Index (ITBEM) value is formulated using the following formula:

Information

$$
I T B E M=\frac{1}{T E E M}
$$

\begin{tabular}{|c|c|c|}
\hline ITBEM & $=$ & Minimum Erosion Danger Rate Index \\
\hline 1 & $=$ & Number One (Determined Number) \\
\hline TBEM & $=$ & Minimum Erosion Danger Rate \\
\hline Note & : & $\begin{array}{l}\text { If TBEM value is less than } 1 \text { (one), } \\
\text { then it is assumed that the value } \\
\text { becomes } 1 \text { (one). It is conducted to } \\
\text { meet the prevailing rule (concept) } \\
\text { (determined by the researcher) in this } \\
\text { equation, that the result of comparison } \\
\text { has to fall on the used scale, which is } \\
0-100 \text {. It is in line with the theory } \\
\text { since by assuming the TBEM value } \\
\text { which is less than } 1 \text { (one) into the } \\
\text { value of } 1 \text { (one), then it will not } \\
\text { change the meaning of the TBEM } \\
\text { quality, which remains in a sustainable } \\
\text { condition. }\end{array}$ \\
\hline
\end{tabular}

\subsubsection{Farmer Revenue}

Farmer Revenue Index (IPPet) value is formulated as follows:

$$
\text { IPPet }=\frac{\text { PFat of resanch DAS (araa) }}{\text { PPatof target rasearhDAS(area })}
$$

$$
\begin{array}{lll}
\begin{array}{l}
\text { Information } \\
\text { PPet of } \\
\text { research } \\
\begin{array}{l}
\text { watershed(area) } \\
\text { PPet of target } \\
\text { research } \\
\text { watershed }
\end{array}
\end{array} & \begin{array}{l}
\text { Farmer Revenue at research } \\
\text { watershed (area) }(\mathrm{Rp} / \mathrm{kk} / \text { year) }
\end{array} \\
\begin{array}{l}
\text { Farmer Revenue which can serve } \\
\text { as comparison (target) for research } \\
\text { watershed (area) }(\mathrm{Rp} / \mathrm{kk} / \text { year) }
\end{array}
\end{array}
$$$$
\text { (area) }
$$

\subsubsection{Crop Production}

Crop Production Index (IPTPa) value is formulated as follows:

$$
I P T P_{\alpha}=\frac{\text { Pptpa of resarch DAS }(a \mathrm{ra})}{\text { Pptpa of targatrasarch DAS(area) }}
$$

$\begin{array}{ll}\begin{array}{l}\text { Information } \\ \text { Pptpa of } \\ \text { research } \\ \text { watershed } \\ \text { (area) }\end{array} & \begin{array}{l}\text { Productivity of agricultural area for } \\ \text { crop at research watershed (area) } \\ \text { (ton/hectare/year) }\end{array} \\ \begin{array}{l}\text { Pptpa of } \\ \text { target } \\ \text { research }\end{array} & \begin{array}{l}\text { Productivity of agricultural area for } \\ \text { crop which can serve as comparison } \\ \text { (target) for research watershed (area) }\end{array}\end{array}$


watershed (ton/hectare/year)

(area)

\subsection{Sustainable Condition of Upper Ciliwung Watershed}

The methods of calculation for IKFD of Ciliwung Hulu are as follows:

\subsubsection{Calculation of Minimum Erosion Danger Rate Index (ITBEM) of Upper Ciliwung Watershed (Real (biophysical) condition of Minimum Erosion Danger Rate (TBEM) indicator of Upper Ciliwung Watershed)}

According to the calculation based on the data and formula used in this research, TBEM value of Upper Ciliwung Watershed is 4.13. Therefore, according to formula (5), Minimum Erosion Danger Rate Index of Upper Ciliwung Watershed is as follows:

$$
\begin{aligned}
\text { ITBEM } & =\frac{1}{4.13} \quad(5) \\
& =0.242 \text { or } 24.2 \%
\end{aligned}
$$

3.5.2 Calculation of Farmer Revenue Index (IPPet) of Upper Ciliwung Watershed (Real (economic) condition of Farmer Revenue indicator at Upper Ciliwung Watershed)

According to the preparation of method of calculation for Watershed Function Sustainability Index (IKFD) of Ciliwung Hulu discussed in the previous sub-chapter, then for the first step, the number of Farmer Revenue of Upper Ciliwung Watershed is Rp 24,060,000. Next is to determine Farmer Revenue which can serve as comparison (target) of Farmer Revenue number at research watershed (area). The area is Batu City (Brantas Watershed). The latest data the researcher obtained is $\operatorname{Rp} 40,500,000 / \mathrm{kk} /$ year [1].

After that, Farmer Revenue Index (IPPet) value of Upper Ciliwung Watershed as in formula (6) is calculated using the following calculation step:

$$
\begin{aligned}
\text { IPPet } & =\frac{\operatorname{Rp} 24060000,-}{\operatorname{Rp} 40,500,000,-} \\
= & 0.594 \text { or } 59.4 \%
\end{aligned}
$$

3.5.3 Calculation of Crop Production Index (IPTPa) of Upper Ciliwung Watershed (Real (biophysical) condition of Crop Production indicator at Upper Ciliwung Watershed)

The value of Crop Production of Upper Ciliwung Watershed based on data processing and analysis methods in this method of research is $25,617.83$ tons/year $[5,8]$.

The next step is to obtain the productivity number of agricultural area for crop at research watershed (area) which can be seen in formula (3).

$$
\text { Pptpa }=\frac{25,617,83}{15,225,12}
$$

$=1.68$

The area of Upper Ciliwung Watershed as stated before is $15,225.12$ hectares.

After that, the number (value) of Crop Production which can serve as comparison (target) for the number (value) of Crop Production at research watershed (area) is determined. The area is Tasikmalaya City (Citanduy Watershed) $[5,8,9,10]$. The Crop Production value of Tasikmalaya City (Citanduy Watershed) is $86,191.61$ tons/year [10].

The next step is to obtain the productivity number of agricultural area for crop at watershed (area) which can serve as comparison (target) (Tasikmalaya City (Citanduy Watershed)) using formula (3).

$$
\begin{aligned}
\text { Pptpa }= & \frac{86,191.61}{17,156} \\
& =5.02
\end{aligned}
$$

The final step is to compare productivity value of agricultural area for crop at research watershed (area) and productivity value of agricultural area for crop at watershed (area) which can serve as comparison (target) of research area, based on formula (7).

$$
\begin{aligned}
\operatorname{IPTPa} & =\frac{1.68}{5.02}(7) \\
& =0.335 \text { or } 33.5 \%
\end{aligned}
$$

\subsubsection{Final calculation of Watershed Function} Sustainability Index (IKFD) value of Ciliwung Hulu

The final calculation of Watershed Function Sustainability Index value of Ciliwung Hulu as specified before, is the multiplication between the number of Analytical Hierarchy Process (AHP) in every watershed function sustainability indicator of Ciliwung Hulu multiplied by each number of index: Minimum Erosion Danger Rate (TBEM), Farmer Revenue, and Crop Production. The calculation for final value of IKFD Ciliwung Hulu uses the following method:

$$
\begin{aligned}
I K F D= & (I T B E M \times 72.8 \%)+(\text { IPPet } \times 15.3 \%)+ \\
& (\text { IPTPa } \times 11.9 \%) \\
= & (24.2 \% \times 72.8 \%)+(59.4 \% \times 15.3 \%)+ \\
& (33.5 \% \times 11.9 \%) \\
= & (17.6 \%)+(9.1 \%)+(4.0 \%) \\
= & 30.7 \%
\end{aligned}
$$

\subsubsection{Range of Watershed Function Sustainability Index (IKFD) Value of Ciliwung Hulu}

The researcher uses the categorization of Environmental Quality Index to categorize Watershed Function Sustainability Index (IKFD) value of Ciliwung Hulu with modification [16]. The perfection (modification) is conducted based on the spread of number in the calculation of watershed function sustainability index of 
Ciliwung Hulu. Table 2 shows the result of categorization by the researcher.

Table 2 Range of IKFD Value for Ciliwung Hulu

\begin{tabular}{|c|c|}
\hline \multicolumn{2}{|c|}{ IKFD Ciliwung Hulu } \\
\hline Excellent & $\mathrm{X}>98$ \\
\hline Very good & $94 \leq \mathrm{X} \leq 98$ \\
\hline Good & $90 \leq \mathrm{X}<94$ \\
\hline Fair & $86 \leq \mathrm{X}<90$ \\
\hline Bad & $57 \leq \mathrm{X}<86$ \\
\hline Very bad & $28 \leq \mathrm{X}<57$ \\
\hline Caution & $\mathrm{X}<28$ \\
\hline
\end{tabular}

Therefore, the obtained IKFD value of Ciliwung Hulu is $30.70 \%$. Referring to Table 2 about Range of IKFD Value of Ciliwung Hulu, then the number is categorized as Very Bad. It calls stakeholders to make actions based on their proportions and capabilities to improve the quality of watershed function sustainability of Ciliwung Hulu.

\section{Conclusion}

The Deforestation and forest degradation are activities that contribute significantly to $17 \%$ of global greenhouse gas emissions [15]. Therefore, in addition to supporting the preservation of watersheds, reducing deforestation and forest degradation is very important in mitigating climate change toward low carbon society.

The Sustainability Condition of Upper Ciliwung Watershed based on the method of calculation for Watershed Function Sustainability Index (IKFD) is $30.7 \%$ (categorized as Very Bad based on the Table of Range of IKFD Value for Ciliwung Hulu).

The authors would like to thank Universitas Indonesia, Hibah Publikasi Internasional Terindeks Untuk Tugas Akhir Mahasiswa UI (PITTA) Tahun 2018 Number: 2582/UN2.R3.1/HKP.05.00/2018.

\section{References}

1. BPS. Analisis Sosial Ekonomi Petani di Jawa Timur. Badan Pusat Statistik Provinsi Jawa Timur (2014)

2. BPSNasional_https://www.bps.go.id/statictable/201 4/09/08/950/rata-rata-konsumsi-per-kapita seminggu-beberapa-macam-bahan-makananpenting-2007-2017.html, April 29 th $^{\text {th }}$, 18 , 2.30 PM.

3. BPS Kabupaten Bogor. (2014). Kabupaten Bogor dalam Angka. Kabupaten Bogor: Badan Pusat Statistik (2018)

4. BPS Kabupaten Bogor. Kabupaten Bogor dalam Angka. Kabupaten Bogor: Badan Pusat Statistik (2016)
5. BPS Kabupaten Bogor. Kabupaten Bogor dalam Angka. Kabupaten Bogor: Badan Pusat Statistik (2017)

6. BPS Kota Bogor. Kota Bogor dalam Angka. Kota Bogor: Badan Pusat Statistik (2014)

7. BPS Kota Bogor. Kota Bogor dalam Angka. Kota Bogor: Badan Pusat Statistik (2016)

8. BPS Kota Bogor. Kota Bogor dalam Angka. Kota Bogor: Badan Pusat Statistik (2017)

9. BPS Kota Batu. Kota Batu dalam Angka. Kota Batu: Badan Pusat Statistik (2017)

10. BPS Kota Tasikmalaya. Kota Tasikmalaya dalam Angka. Kota Tasikmalaya: Badan Pusat Statistik (2017)

11. BPS Kabupaten Bogor. Kabupaten Bogor dalam Angka. Kabupaten Bogor: Badan Pusat Statistik (2017)

12. C. Suryadi. Wilayah Prioritas Konservasi Tanah di DA Ciliwung Hulu [Tesis]. Depok: Program Magister Ilmu Geografi Fakultas Matematika dan Ilmu Pengetahuan Alam (2011)

13. E. Anas. Simulasi Pengendalian Erosi dengan Menggunakan Model AGNPS (Agricultural NonPoint Source) di Sub DAS Cikundul, Kabupaten Cianjur [Skripsi]. Bogor: Departemen Teknik Pertanian Fakultas Teknologi Pertanian Institut Pertanian Bogor (2007)

14. I. B. Pramono, E. Savitri, S. Donie, T.M., A.B. Supargat, S.A. Cahyono, R. Bambang. Restorasi DAS Ciliwung. Surakarta: Sebelas Maret University Press (2016)

15. IPCC. Mitigation of Climate Change. Working Group III Fourth Assessment Report. Intergovernmental Panel on Climate Change, IPCC (2007)

16. KLHK. Indeks Kualitas Lingkungan Hidup Indonesia 2014. Jakarta: Kementerian Lingkungan Hidup dan Kehutanan Republik Indonesia (2014)

17. KLHK. Peta Tutupan Lahan Daerah Aliran Sungai Ciliwung. Jakarta: Kementerian Lingkungan Hidup dan Kehutanan Republik Indonesia (2015)

18. KLHK. Peta Tutupan Lahan Daerah Aliran Sungai Ciliwung. Jakarta: Kementerian Lingkungan Hidup dan Kehutanan Republik Indonesia (2017)

19. M. Karuniasa. Model Restorasi Lingkungan Untuk Keberlanjutan Fungsi Ekosistem Daerah Aliran Sungai [Disertasi]. Jakarta: Program Pascasarjana Program Studi Ilmu Lingkungan Universitas Indonesia (2012) 